\title{
Globalisation and Construction of Local Culture in Rural Sri Lanka
}

\author{
Upali Pannilage ${ }^{a}$
}

\begin{abstract}
Globalisation refers to a complex process of increasing interdependence, integration, and interaction among individuals, societies, cultures, and institutions around the world in the spheres of economy, culture, knowledge, technology, and politics. The impacts of globalisation especially during the last few centuries have been spread throughout the globe. Although, the implications of globalisation on the economies and international relations have been discussed widely, its impacts on the society and culture especially in the context of rural Sri Lanka have not been studied and analysed adequately. Therefore, this paper has examined the factors that have been contributed to the construction of local culture in the rural Sri Lankan society. The qualitative analysis has included theoretical explanation to the globalisation and culture which has followed with a review of literatures on the recent studies on impacts of globalisation on the local culture in the rural Sri Lankan society. The paper concludes that there are significant influences from the globalisation process to construct the local culture of rural Sri Lanka.
\end{abstract}

Keywords

Culture, globalisation, impact, rural, Sri Lanka

The Sri Lankan society is at a rapid change process due to various socio-economic and political reasons. As a result of the change process of the society, the local culture that is practiced by the people especially living in rural villages in the country has been reshaped from its original shape. Since the globalisation process has been spread throughout the globe during last few centuries, this paper has made an attempt to examine the influence of globalisation in order to construct the culture in rural Sri Lankan society. Therefore, the problem which is investigated is how the local culture has been constructed by the globalisation process and what factors have contributed to the construction of culture in rural areas of Sri Lanka. In line with these research problems, the overall objective of the paper is to analyse the ways and means that the globalisation process has influenced the local culture in Sri Lanka.

The paper is based on secondary sources of information drawn from various literatures on the subject. The paper has been organized under five thematic areas. The first subheading of the paper has been used to provide a detailed account on the definitions of globalisation and also to emphasise the evolution nature of the globalisation. Then, a brief introduction has been provided on the main theories of globalisation in order to place the paper in an appropriate theoretical framework. The third subheading of the paper has been named as globalisation and

aUniversity of Ruhuna, Matara, Sri Lanka

\section{Correspondent Author:}

Upali Pannilage, Department of Sociology, University of Ruhuna, Matara, Sri Lanka 
culture where mainly the culture and cultural globalisation has been emphasized. The section on Sri Lankan society in the context of globalisation has provided an account on the Sri Lankan society and culture from the beginning highlighting major milestones. Immediately after this section, a literature review has been included on the recent studies of culture and globalisation in Sri Lanka. After this section, the paper has discussed key findings of the paper and then finally conclusions have been incorporated.

\section{GLOBALISATION: DEFINITIONS AND EVOLUTION}

Although, there is not any accepted single definition for globalisation, Turner (2011: 9-10) has made an attempt to define some of its main contours:

(1) the growing frequency, volume and interrelatedness of cultures, commodities, information, and peoples across both time and space; (2) the increasing capacity of information technologies to reduce and compress time and space (giving rice to notions such as the global village); (3) the diffusion of routing practices and protocols for processing global flows of information, money, commodities and people; and (4) the emergence of institutions and social movements to promote, regulate, oversee or reject globalisation; and (5) the emergence of new types of global consciousness or ideologies of globalism that give some expression to this social interconnectedness such as cosmopolitanism.

Giddens (2009: 126) wrote that "globalisation refers to the fact that we all increasingly live in one world, so that individuals, groups and nations become ever more interdependent".

There are two main perspectives on the evolution of globalisation: One is that globalisation is a novel concept which began with the attempted trade and economic policies of United States of America (USA) which were introduced by President Ronald Regan ${ }^{1}$ in mid 1980s. The second perspective is that although the word "globalisation" was not in use, the process of globalisation existed, which had evolved through many centuries. The term westernization ${ }^{2}$ is discussed mostly in Asian, African, and Latin American countries: It means the expansion and influence of western culture, social values, and politics, to the non-western nations in the world.

The colonization ${ }^{3}$ which was intensified in the sixteenth and seventeenth centuries and its effects during nineteenth to twentieth centuries contributed to increasing trading from and to the west. It was not called as globalisation during that time. However, the colonization process contributed significantly to expanding trade around the world. Later on, during the 1970s, trade liberation expanded through Western European countries including the United Kingdom (UK) and the USA. Those attempts of trade liberalization have made huge impacts on the economic globalisation process throughout the world. By the early twentieth century, the USA had become the world's leading industrialized nation. Notions of an indirect persistence of US hegemony are most closely linked to the development of globalisation perspectives (Youngs 2007: 4). Meantime, Antonio (2004: 176) argued that the political economy of the USA has a profoundly financial, social, cultural, and political influence on the process of globalisation throughout the world. "During the Clinton ${ }^{4}$ presidency, globalisation accelerated and expanded so aggressively that voices of concern began to coalesce and organize throughout the world, by articulating popular movements as in Seattle and elsewhere" (Gill 2000; Halliday 2000; Kaldor 2000; Scholte 2000). "The impact of Reaganomics on cultural practices was perhaps even more extensive than in the economic and financial fields. In Reagan's years, the robust nexus between politics, economics, military and the expansion of mass consumerism was amplified through the media industry" (Barber 2008; Moffitt 1987).

The most recent and advanced stage of the globalisation process can be seen with the large scale 
expansion of multinational and transnational corporations and neo-colonization. Introduction of the first multinational company under the name of Standard Oil Trust by the Rockefeller foundation in USA is considered as the first multinational company in the world. Since then, millions of multinational companies have been established in almost all the sectors and are in the process of contributing to the process of globalisation significantly. Together with multinational companies, the international financing organizations such as the World Bank and International Monetary Fund (IMF) contribute significantly in the process of neo-colonization as well.

\section{THEORETICAL PERSPECTIVES OF GLOBALISATION}

While the globalisation itself stands as a theory, there are a number of theories on globalisation from multi-dimensional perspectives. Although, it was not called as globalisation, one of the early attempts in similar nature can be understood from the work explained by Immanuel Wallerstein who develops a theoretical frame to understand the historical changes involved in the rise of the modern world. Accordingly, "the modern world system was capitalist and followed the crisis of the feudal system of the Europe. The system explained the rise of Western Europe to world supremacy between 1450 and 1670". Wallerstein (1998) mentioned that "a world-system is a social system, one that has boundaries, structures, member groups, rules of legitimation, and coherence". His arguments were explained in a three-volume work, The Modern World-System (1974; 1980; 1989). The origins of the modern world-system go to the sixteenth and seventeenth-century Europe, where colonialism enabled countries like Britain, Holland (Netherlands), and France to exploit the resources of the countries they colonized.

Wallerstein argues that the process produced a world-system made up of a core, a semi-periphery and a periphery. And although it is clearly possible for individual countries to move "up" into the core - as have some newly industrialized societies or to drop "down" into the semi-periphery and periphery; the structure of the modern world-system remains constant. (Giddens 2009: 128)

In the year 1997, Meyer, Boli, Thomas, and Ramirez developed world polity theory as an analytical frame for interpreting global relations, structures, and practices. "The world polity theory view the primary component of the world society as 'world polity', which provides a set of cultural norms or directions in which the actors of the world society follow in dealing with problems and general procedures" (Meyer et al. 1997). As explained by Meyer (1980) "while world polity theory define sovereign states as key actors, enabling authorities to construct collective goals and devise the means or programs to produce them, state officials are not the only ones engaged in such authoritative creation of value".

In the same year as world polity theory, the work on world culture theory was also introduced. World culture theory explained that:

The globalisation focuses on the way in which participants in the process become conscious of and give meaning to living in the world as a single place. In this account, globalisation "refers both to the compression of the world and the intensification of consciousness of the world as a whole"; in other words, it covers the acceleration in concrete global interdependence and in consciousness of the global whole. (Robertson 1997: 8)

As per this theory, cultural globalisation will share certain characteristics of other globalisation processes, namely the weakening or disappearance of borders among nations, societies, and ethnicities, and simultaneous unfolding of events on a global scale. Meantime, these things unfold principally as a result of competition in the free market.

George Ritzer $(1996 ; 2006)$ introduced the theory of McDonaldization which has been widely discussed 
in the field of sociology. This theory is based on and explains the process of rationalization. The process of McDonaldization takes a task and breaks it down into smaller tasks. This is repeated until all tasks have been broken down to the smallest possible level. Ritzer (1996) argued that "there are four main dimensions of McDonalisation namely efficiency, calculability, predictability and control".

Robertson (1990; 1992; 1997) theorized the glocalisation which emphasised on the cultural globalisation. Glocalisation means a situation in which a global product is transformed into another shape in order to meet the needs of local consumers. Robertson argued that the conception of globalisation is built upon "the establishment of cultural, social, and phenomenological linkages between the self, the national society, the international system of societies and humanity".

Giddens introduced the theory of "time-space distanciation". Accordingly, social life consists of interactions that are face-to-face or remote. "Time-space distanciation describes the process whereby remote interaction has become an increasingly significant feature of human life, and through which social systems that were previously distinctive have become connected and interdependent". Giddens (2009) defined globalisation as "the intensification of worldwide social relations which link distant localities in such a way that local happenings are shaped by events occurring many miles away and vice versa".

Beck (1992) introduced the theory of "Risk Society". His publication on Risk Society: Toward a New Modernity was first published in German in the year 1986 and translated into English in the year 1992. Beck concentrated on the political, economic, and social globalisation. Beck's theoretical frame comprises three inter-related components namely: (1) risk; (2) individualisation; and (3) reflexive modernization.

Arjun Appadurai introduced the theory of "Social
Imaginary". Appadurai (1996) defined globalisation characterised by two forces as mass migration and electronic mediation. He argued that "the complexity of global economy has to do with certain fundamental disjunctures between economy, culture, and policies that we can understand through cultural flows".

The theory introduced by Manuel Castells has been named as "Network Society". Castells (2000; 2010) explained that "globalisation is a shift emphasis from post-industrialism to informationalism". $\mathrm{He}$ defined globalisation as the emergence of informationalism that is the new material, technological basis of economic activity and social organisation. Castells' thesis, The Rise of the Network Society (2000; 2010), illustrates a "technologistic" approach to globalisation.

\section{GLOBALISATION AND CULTURE}

The study of culture was first used by the pioneer Anthropologist Edward B. Tylor, in his most famous publication Primitive Culture (1971). Accordingly, "culture is the complex whole, which includes knowledge, belief, art, law, morals, custom, and any other capabilities and habits acquired by man as a member of society". As per this definition, the term culture has a broad meaning in the society. Human being as a member of the society acquired various capabilities and habits which Tylor explained as the culture. The complex whole which Tylor defined as the culture has multi-dimensional societal factors which include knowledge, belief, morals, and customs.

The human way of life is based on socially learned understandings that are shared among the members of a group. Many of these understandings are learned as part of the process of growing up. They carry what might be called a "moral charge", and those who share them feel the understanding "ought" to be followed. These socially learned and morally forceful understandings make up what is called "culture". 
Culture is the foundation of human life. Through the operation of their culture the members of a group are able to get along with one another well enough to maintain social relations and to provide for their survival needs. The culture of a group is the sum of the morally forceful understandings acquired by learning and shared by the members of that group. (Swartz and David 1980: 79)

"Cultural relativism is the recognition that the members of every group behave according to their own culture and that any attempt to understand them without reference to that culture will fail" (Swartz and David 1980: 80).

As explained by Recherson (2005: 3),

Culture is information that people acquire from others by teaching, imitation and other forms of social learning. On a scale unknown in any other species, people acquire skills, beliefs, and values from the people around them, and these strongly affect behavior. People living in human populations are inheritors to a pool of society transmitted information that affects how they make a living, how they communicate, and what they think is right and wrong. The information thus stored and transmitted varies from individual to individual and is a property of the population only in a statistical sense.

\section{As defined by Giddens (2009: 54),}

Culture consists of the values the members of a group hold, the languages they speak, the symbols they revere, the norms they follow, and the material goods they create. Some elements of culture, especially people's beliefs and expectations about one another and about the world they inhabit, are a component of all social relations.

Anderson and Howard (2004: 58) mentioned that:

Culture is both material and nonmaterial. Material culture consists of the objects created in a given society, which are its buildings, art, tools, toys, print and broadcast media, and other tangible objects. In the popular mind, material artifacts constitute culture because they can be collected in museums or archives and analyzed for what they represent. These objects are significant because of the meaning they are given.

In summary, the culture includes various kinds of traditions, norms, and symbols that shape and are conceded as feelings, thoughts, and behaviors of segments of people. Referring primarily to learning behavior as distinct from which is given by nature or biology, culture has been used to designate everything that is humanly produced (habits, beliefs, arts, and artifacts) and transfer from one generation to another. In this formulation, culture is distinguished from nature, and distinguishes one society from another.

"Globalisation was a term used by anthropologies and sociologies to discuss cultural changes well before its widespread use in discussions of economics and business" (Simon 2007: 36). Globalisation process impacts on cultural and economic factors as the main determinants which affect the social and political conditions of nations, which is similar to the Max Weber's theories. Accordingly, the systems of social values, beliefs, and the pattern of identity of dominant and the subordinate groups within a society are important elements to explain national characteristics in economic and social terms. Cultural globalisation is a key concept in the discourses with regards to globalisation and its impacts. According to Kumaravadivelu (2008), cultural globalisation refers to the way that how "contact between people and their cultures, their ideas, their values, their ways of life have been growing and deepening in unprecedented ways". Therefore, cultural globalisation can be understood in three models: (1) cultural homogenization; (2) cultural heterogenization; and (3) cultural glocalization. As per this explanation, "cultural homogenization means that cultural globalisation is the progressive spreading of one dominant culture outward to other cultures". Cultural heterogenization means that cultural globalisation has actually led to a rise in preservation of local cultures, mainly as a reaction against subsumption by a dominant culture. Cultural glocalization model refers to "simultaneous homogeneous and heterogeneous cultural development" (Kinberg 2009; Kumaravadivelu 2008; Liu 2012: 96). 
As same as the colonization, the impact of the globalisation has been more serious on economy, society, polity, and culture of rural Sri Lankan society which is largely village based. The socio-economic changes experienced by the rural society in Sri Lanka were even more rapid in the age of globalisation than the period of colonialism. These interventions may have impacted considerably on the society for its drastic changes during last few decades which contributed to the construction of its culture.

\section{SRI LANKAN SOCIETY AND CULTURE FROM HISTORY TO THE ERA OF GLOBALISATION}

Sri Lanka is an island surrounded by the Indian Ocean. The Island is a 65,610 square-kilometer teardrop off the southeast tip of the Indian subcontinent. It is separated from the continent by the Palk Strait and Gulf of Mannar, but a chain of island and sand bars known as Adam's Bridge links them. It is about 400 kilometers at its widest point (Peebles 2006). Historically, Sri Lanka is unique in the world because it has clear written history over 3,000 years. No other country has such a long documented history. The history of Island was documented in the chronicles named the Dipawamsa written in forth century AD and the Mahāwamsa written in fifth century $\mathrm{AD}$ (Geiger 1912).

According to the chronicles records of the Island,

History begins in 543 B.C. with the landing of Indian Prince of Vijaya who sailed with 700 followers on eight ships from South-West coast of India. After arrival to the country, they established a kingdom in the Island which called Thambapanni. Although the Chronicles says that the Island history starts at 543 B.C., archeological excavation found evidences that the history goes back to 125000 years (Deraniyagala 1988).

Archeologists argued that this human culture depicted a highly developed stone culture through
Rock Caves and Shelters (Deraniyagala 1988). The earliest chronicles from the Island, the Dipavamsa and the Mahavamsa, say that tribes of Yakkhas (demon worshippers), Nagas (cobra worshippers), and Devas (god worshippers) inhabited the Island prior to the migration of Vijaya. Chinese traveler Fa-Hsiens' records also mention the same (Deraniyagala 1988). According to Mahavamsa, the first inhabitants were led by Prince Vijaya and the Yakkhas and Nagas descended from a liaison between Vijaya and a she-devil (kuveni) (Bullis 2005). In the prehistoric era of this Island, there were a small group of people called "Veddas" having primitive culture and even today living in some parts of the Island (C. G. Seligmann and B. Z. Seligmann 2003). They may be the inhabitants of those descendants. As a matter of fact, the prehistory of Sri Lanka emerges from those early days of many myths and legends.

The Sri Lankan society is in effect the story of Buddhism and its all-pervading influence on her people and institutions. Buddhism was introduced to the Sri Lanka in 247 BC. The message of Buddhism was sent by the powerful emperor King Ashoka from India. The whole society including the king embraced the Buddhism because there was not established religion in Sri Lanka by that time. Within a short period of time, Buddhism was permanently rooted in Sri Lankan society and many Buddhist rituals were added to the society. Answering the question: Why did Buddhism spread so successfully? Richard Gombrich mentioned that "the major factor has no doubt been the power and beauty of its thought. It offered both a coherent, universalistic ethic and a way to salvation from suffering" (Gombrich 1988). With Buddhism in Sri Lankan society, people received not only Buddhist religion but also received the knowledge of irrigation, architecture, painting, art, literature, etc. Therefore, Buddhism was blended with the Sinhalese society and culture.

Till the sixteenth century, Sinhalese kings ruled the country but time to time they were interrupted by 
the invaders of South India. At the beginning of sixteenth century,

Portuguese came to the country and began the age of westerner's conquest and influenced the people and the Island. They got the permission from the King of the Sri Lanka to have a small sea-port but later on they expanded the area almost whole maritime regions. In $1658 \mathrm{AD}$, the Dutch came and ousted the Portuguese and ruled over almost the same region until the British came in. The British, ousted the Dutch from the Island and raised the British Flag in same areas in 1796 AD. (Codrington 2009)

The Sri Lanka became a British colony since then until 1948 AD.

Sri Lanka was ruled by the Sinhala kings for over 2,550 years. But, Sri Lanka's early modern period began with the arrival of Europeans since the sixteenth century. Sri Lankan traditional society was considerably changed due to the influence of these colonial periods. From the ancient time, the Sri Lankan society has been known as a society with numerous traditions inbuilt into the day to day lives of its citizens. There were valuable social backgrounds in traditional society, derived from devoted roles and responsibilities of the social institutions.

During the colonial era, Sri Lanka received common colonial heritage of Asia. The project of western missionaries during the colonial era to popularise their religion considerably contributed to the construction of Sri Lankan culture in line with the western nature of behaviours, belifes, and customs. The old Buddhist cultural activities such as religious rituals and customs were deprived by the British. (Hettige 2000)

Sri Lankan traditional economy was based on agriculture which marked the rural continuum of the country. "It was consisted mostly of rice-growing peasantry. Apart from rice-growing, there were various craftsmen such as metal workers, potter makers and service personal such as washer-men and load-carriers. The colonial economy was replaced with non-traditional cultivation of Tea, Rubber, Cinnamon and Coconuts" (Jayawardena 2007). The colonial government paid no attention to the traditional entrepreneur and the state encouraged the private sector also to play their role in developing the land and economy in non-traditional cultivation. Therefore, the state neglected the traditional cultivation as well as indigenes irrigation system and the lands. To bring the production to the ports, the British colonisers developed the roads system including railways particularly in those cultivated areas to the main cities.

Sri Lankan society was mainly an agriculture based one, people engaged in chena cultivation which cultivated annually and produced almost everything they wanted for their consumption. When a villager was in need of a consumer item, he or she obtained it from another one by exchanging a consumer item with him or her.

The exchange economy system was changed into the money economy system in the colonial era. The cultivation of commercial crops like tea, rubber, coconut and cinnamon was introduced in the face of other traditional crops. At the time of political independence, the fact that Sri Lanka was better off than the bulk of its Asian neighboring countries has been widely acknowledged by socio-economic analysts, policy makers, politicians and even the general public. (Abeyratne 2000)

With independence, the Sri Lankan government took up the practice of economic development and careful planning. There was little experience and no institutional structure to set priorities or follow a consistent set of policies (Morrison and Hasbullah 2004). Later on, in the year 1977, the Open Market System was introduced to the country. Through this open and free market system, export and import based economy was established. The introduction of open and free market economic system to the country can be considered as a major landmark which contributed to the changes in the economy, society, and culture of the country.

In the traditional Sri Lankan society, the family system was an extended one where the children lived 
with their parents and their grandparents.

Roles and responsibilities of each member of the family were socially allocated and shared by the members of the family. The family acted as main system with responsibilities on the production, reproduction and care. Since the production system was mainly depending on subsistence agriculture, required labor for agricultural work was supplied by the family itself. (Yalman 1967: 106)

There was no or very limited use of machineries in the agricultural activities as the cultivation was mainly done with primitive technologies. As "whole production system was based on the agriculture, land became major property in the family which was shared and protected within the family system" (Yalman 1967: 97-98). The ownership of the land was transferred from generation to generation.

The marriages were took place mainly on the basis of protection of land and property of the family. The traditional extended family ${ }^{5}$ system of the Sri Lankan society was changed slowly during the colonial period and then rapid changes can be observed with the economic liberalization as part of free and open economy introduced in the year 1977/1978. The subsistence agricultural based economy was changed into a market-oriented economy where service economy could be seen with the introduction of cash crops such as tea, coffee, rubber, etc. in the colonial period. The economy was further changed with labor force engagement in paid jobs including industrial and service sectors. The increase of population caused decrease of the available lands for subsistence agricultures as lands were utilised in order to produce goods for export market. This export market system significantly contributed to changing the life styles of the traditional folks of the Sri Lankan society.

The traditional extended family system could not continue as members of the family have to engage in income earning activities to maintain the family economy. The social care of grandparents within the family could not be continued and nuclear family ${ }^{6}$ system emerged where only the parents and their children are living together. Moreover, the structure of marriage system changed with growing modifications in other institutions such as education, employment. For instance, increasingly, women and men are accepted as self-directing individuals, capable of making their own decisions about marriage and child-bearing. (Morrison and Hasbullah 2004)

At present, the Sri Lankan society is multi-ethnic, multi-religious, and multi-languages, which contributes to the construction of multi-culture. The population is made up of diverse groups: Sinhala, Sri Lanka Tamil, Indian Tamil, Sri Lankan Yonaka (Muslims), Burgher, Malay, Sri Lankan Chetty, Bharatha, and others. Among those ethnic groups, Indian Tamils, Burgher, Malay, and Sri Lankan Chetty are alleviating today in the society. As a matter of fact, the number of the population of some ethnic groups is too small and not recognized today. As per the census data at present, basically, $74.9 \%$ of population is Sinhalese, $11.2 \%$ is Tamils, and $9.3 \%$ of population is Yonakas (Muslims) (Department of Census and Statistics 2012).

There are four major religions in the country as: Buddhism, Hinduism, Christianity, and Islam practitioners. More than $70 \%$ of population is Buddhist and $12.6 \%$ of population is Hindus (Department of Census and Statistics 2012). The other religious communities are too small when they are concerning to the mainstream. "The majority of the Sinhalese and Tamil population remained as Buddhists and Hindus respectively in the traditional society. Islam was introduced by the Arab traders" (Yogasundaram 2006: 172). With the arrival of Portuguese, Catholic religion was introduced to the country. "In the colonial period, being Catholic was privileged matter and religious conversion was practiced during the colonization period" (Jayawardena 2007).

There has been Hindu invaded in the Island in the fifth, ninth, tenth, eleventh, and thirteenth centuries. During these periods, the Hindus culminated the establishment of the Hindu religion. Mostly, they 
invaded and ruled the northern part of the Island. Apart from this, many Sri Lankan kings imported their wives from India. Those wives who came with relatives and friends brought the Hinduism to this society. The descendants of those wives began to practice Hinduism with the support of the kings. Hinduism was the major religion of the Indian society and there are possibilities that it may come automatically to the Sri Lanka which is the close neighboring country and had a close relationship from the ancient time. Moreover, many Indians visited the Island and established their lives here.

Christianity was introduced to country during the colonial period. The missionaries propagated Christianity in three main ways: (1) by education; (2) by preaching; and (3) by pamphleteering. Every mission station had a primary school and the Church of England which maintained an institution to train school teachers and ordinance. To get some privileges, many Sri Lankan embraced the Christianity during the colonial period and after the independence, some returned to their origin. Muslims never invaded the Island or ruled the country although currently $9.2 \%$ of population is Muslims. Main livelihood of Muslims was the trading and they travelled far away for that purpose. There is some archeological evidence that Muslims have visited the Island from the ancient time. For instance; there are some ancient coins which belong to the West Asian countries found in many parts of Sri Lanka.

In this context, scholars argue that modern Sinhalese society practices only popular Buddhism in contrast to original Buddhism. Gombrich (1988) named this as "Protestant Buddhism". As a matter of fact, Gombrich's statement is true when observing carefully the practice of the Buddhism in the Sinhalese society. Since at the beginning of fifth century A.D., Sinhalese Buddhism has mixed with Hinduism that has magic and exorcism but the Buddhist values of compassion and non-violence have dictated that no gods can receive blood sacrifices. Thus, almost all Sinhalese followers of Buddhism practice those magic and exorcism. Many call this as Sinhalese folk religion and today Sinhalese religious pantheon includes a cult of gods and goddess, planetary deities, demons, and meaner sprits. In this religious pantheon, the top hierarchy is the Buddha and all others are in the secondary places.

From the sociological point of view, the study of religions can be done through living part of it. The living part of religions is the ritual that reveals people's behaviors and beliefs. Durkheim strongly emphasized that all religions involve regular ceremonial and ritual activities (Giddens 2006: 537-538). Regarding the rituals, Eric Sharp mentioned that "in the study of religion, ritual means traditional religious behavior or actions" (Sharp 1971: 56). Almost all Buddhist temples in Sri Lanka have shrine rooms for gods and goddess. Their favours are invoked by making various kinds of offerings including fruits, flowers, incense, etc., which are called "Deva Puja". Today, there are various deva pujas held for healing purposes and achieving worldly objectives such as success at interviews, examinations, to win election, to get prosperity, and so on. Many Sinhalese Buddhists as well as Sinhalese Christians believe that they get bad luck; weakness, illness, and a period of difficulties are to be caused by these planetary deities. To get out of these kinds of things, people perform various kinds of rituals.

Some of people in Sri Lanka believe that humans could be frightened or even possessed by demons and such other evil spirits. These situations normally cause mental problems and even very serious hysterical conditions. For these illnesses, some people in Sri Lanka seek the help of rituals called "yatukamma" which includes "Bali-Tovil", "Yakum", and Mantra japa-kireem (repeated chanting mystic verse) done by a particular person called "Kattadirala" or "Yakadura" who is a kind of exorcists (Kapferer 1983). However, "the simple ways of living changed due to the influence of colonial period. Western words were entered into the vocabularies of both Sinhalese 
and Tamils" (Yogasundaram 2006: 173).

\section{RECENT STUDIES ON GLOBALISATION AND CULTURE IN SRI LANKA}

De Silva (2000) has examined globalisation and the transformation of planetary rituals in Southern Sri Lanka, which is useful to understand the changing situation of traditional Sinhala Buddhist rituals. He argued that, "traditional rituals reforming, rearranging and more clearly reconstructing are modes of expressing Sinhala nationalist sentiment in contemporary Sri Lanka rather than an attempt to preserve or conserve the traditional rituals from the influence of global culture". He stated that while it is difficult to see how public performances can protect traditional forms of culture from external influences particularly from the process of globalisation, they nevertheless seem to reinforce a shared cultural identity and some forms of ethnic unity among the Sinhalese.

Hettige (2000) has examined globalisation and local culture, the case of Sri Lanka and highlighted that the economic liberalization in Sri Lanka could bring many cultural changes and identify globalisation and internationalization together in order to identify the change he refers to. Moreover,

Those who were engaged in a cultural critique of the post-1977 focused on several issues such as decline of local arts under the influence of intruding Western mass media, decline of human bonds under the growing influence of naked materialism, deterioration of sexual morals under the influence of tourism and overseas travel by female workers, and the spread of Western lifestyles and behaviour patterns which allegedly undermine or devalue native ways of life. (Hettige 2000)

Further, his study noted that how the class behaviour was prominent referring to the cultural changes as a result of the new freedoms and possibilities brought about by the liberal economic policies. For instance,
The new rich who tend to adopt modern consumerist lifestyles threatened the native artists, the literati and civil servants. The post-1977 reforms could change the culture and it is twofold; the first pertained to the tension between high and mass culture while the second was related with the alleged subversion of "national culture" by external cultural invasions of imported symbolic goods such as tele dramas, musical shows. (Hettige 2000)

Attanayake (2001) has conducted a study on cultural impact of globalisation on the Sri Lankan society. Accordingly, impact of globalisation on Sri Lankan culture has the following guesses on popular culture.

In acquiring global knowledge in English in formalized structures, it has been unable to penetrate the educational system of the masses: only a small section of the well to do groups in the society has been successful in achieving global education facilities. In day to day habits, the gap has increased widely under the process of globalization.

"The post-colonial Sri Lankan studies inherent contradictions and status quote that followed in wider cultural relations are standing against the equal assimilation of global achievements" (Attanayake 2001). As per this analysis, the popular culture is spreading throughout the Sri Lankan society as a result of impact of the globalisation process. Accordingly, globalisation has contributed to constructing the society and culture of the country.

Ranaweera Banda (2013) has studied the cultural dynamics and experts' knowledge focusing responses on transnational culture in a rural community in Sri Lanka. Using anthropological approach, he has examined the ways and means of local communities' responses to the transnational culture which is transmitted to the local society by outsiders (the West). Accordingly,

Local people define their socio-cultural position within two different realms, i.e., inner and outer realms. Of the two, the inner realm which people interact in the day to day life is more important in terms of their local culture than the outer realm. The outer realm is much more liberal than the inner 
realm as it allows the community members to absorb alien values, if desired. The inner realm functions as a mechanism within which community members can understand one another in accordance with a set of cultural norms. (Ranaweera Banda 2013)

He further argued that the Western colonization and modernization has considerably influenced the Sri Lankan society towards modernity. The West has invented some modest forms of cultural differences after the decolonization period. Instead of earlier terminology of "civilized" and "uncivilized", a new set of terms ("developed" and "underdeveloped") was invented in the decolonization period to differentiate the West from the rest of the world.

\section{FINDINGS AND DISCUSSIONS}

Although there were scholarly works to explain that the globalisation is an evolving process of the world history since centuries, in line with many other similar discourses and processes which are related to colonisation, internationalisation, universalization, and Westernization, the literature in this paper highlighted the deliberate involvements of western world in imposing the globalisation process throughout the globe. The evolutionary explanation of the Sri Lankan society through ancient time to the era of globalisation through free market economy, and the review of previous studies on globalisation and Sri Lankan culture, revealed that there is a culture change process that has begun as a result of the globalisation. The trade liberalization and related reform process that has been introduced since the year 1978 with the introduction of free and open market policies has contributed to reshaping the local economy and culture of the country.

The analysis revealed that there were remarkable impacts on the local culture as a result of outside interventions that have been brought as a result of social change process. Some of the changes could be identified as a gradual process due to the evolution nature of the society while some of changes could explain as results of the reforms taking place in the western world and imposement of those reforms to the country, mainly through the process of globalisation. For example, in the past, the traditional family in the country has been formed based on local norms and practices of caste, neighborhood, and kinship. The marriages have been considered about these factors and the village had autonomy on making decisions about the way that they formed the family as the decisions were made by the members of the family. The gatherings and ceremonies of weddings were conducted in the village itself, showing the independent autonomy of the village in the decision making and implementation process. However, as a result of introduction of Victorian mode of marriage system and subsequent changes as a result of globalisation process on the local culture, those traditional systems connected with the formation of family are in the process of rapid changes in the village resulting that the autonomy that was there for the family and the village to make decisions and act accordingly on the formation of family and conducting marriage ceremonies has been taken over by the market forces outside the village. Meantime, it was found that family, the basic social institution of the society with direct links to the cultural practices of rural society, also slowly modernised due to the change process brought by the globalisation processes.

The analysis of the paper revealed that people have moved away from the traditional subsistence and self-sufficient economic system due to the process of global trading and marketing which has been brought to the country as a result of the globalisation process. The village based self-sufficient economic system prior to the introduction of cash crop cultivation as part of introducing capitalist economy into the country has been changed considerably. The state and private sector involvements by way of introduction of cash crops and related infrastructure were the land mark that has contributed to its remarkable culture change 
process as a result of transformation of the local economy from self-sufficiency subsistence to a capitalist market based economy.

The economic dependency in the society has been created as a result of people moving away from subsistence and self-sufficient agriculture based economy. Moving away from cultivation for consumption leads to creating market dependency for consumer needs, which has contributed to creating economic dependency. The cash crops economy is highly dependent one and people have to rely on market mechanism for each and everything. This process leads to a consumer culture through the interdependency for production as well as for consumption. Production for markets and thereby creation of consumer culture has contributed for considerable changes in the living patterns of the people, which has substantial changes in the gender roles of the society as well.

The discussions and analysis in the paper revealed that the Sri Lankan society has globalised in terms of adaptation to the global socio-economic and cultural processes. Therefore, the phenomenon on ways and means of which the rural society in Sri Lanka has globalised is linked with the Westernisation which means moving towards western model of social system that largely deals with the monetarisation of the society, culture, economy, and the political system.

\section{CONCLUSIONS}

Based on the discussions and findings of this paper, it is concluded that a significant cultural change process has commenced in the village based rural society of Sri Lanka with the incorporation of the village into a broader societal system which is capitalist in nature and oriented towards western style of social institutions, governance systems, and cultural practices. The social collectiveness, togetherness, and morality that were associated with the previous subsistence based on self-sufficient economic system disappeared as a result of this process. Commodification of almost everything in the society including social norms and values has paved a way to cultural modernization. Accumulation of material wealth has become a goal in the socio-economic life of people. The norm of mutuality, which was a fundamental characteristic of traditional rural Sri Lanka, is considerably disappearing while monetary based relations have emerged.

\section{Notes}

1. Ronald Reagan (1911-2004), the 40th President of USA, served office from 1981 to 1989.

2. "Westernization is a concept that is often perceived as being coterminous with globalisation. The term has a strong negative connotation attached to it, due to linkages with earlier periods of Western imperialism and colonialism. Not only economic and political, but Westernization includes other influences such as technology, language, law, lifestyle, and food. As opposed to the unidirectional flow implied by Westernization, globalisation involves multi-directional flows. Westernization implies homogenization, while globalisation involves both homogenization and heterogenization. In addition, through its focus on the West, Westernization also ignores the linkages among countries in the periphery" (Ritzer 2010: 82).

3. "Colonialism is clearly related to imperialism (Williams and Chrisman 1994), and is sometimes used interchangeably with it, but it has a more specific meaning. At the most extreme, imperialism involves a control without the creation of colonies (Harvey 2006: 21). Colonialism generally involves settlers as well as much more formal mechanisms of control than imperialism. Thus, colonialism often entails the creation by the colonial power in the country (or geographic area) that has been colonized of an administrative apparatus to run its internal affairs, including its settlements" (cited in Ritzer 2010: 69).

4. Bill Clinton (1946- ), the 42nd President of USA, served in office from 1993 to 2001.

5. "When close relatives other than a married couple and children live either in the same household or in a close and continuous relationship with one another, it is called an extended family" (Giddens 2009).

6. "The individual nuclear family is a universal social phenomenon. It can be defined as a small group composed of husband and wife and immature children which constitutes a unit apart from the rest of the community" (Rao 2000). 


\section{References}

Abeyratne, S. 2000. "Policy and Political Issues in Economic Growth of Sri Lanka." In Sri Lanka at Crossroads: Dilemmas and Prospects After 50 Years of Independence, edited by S. T. Hettige and M. Mayer. New Delhi: Rajiv Beri for Macmillan India Limited.

Anderson, L. M. and F. T. Howard. 2004. Sociology: Understanding a Diverse Society. Canada: Wadsworth Publications.

Antonio, R. L. 2004. Globalisation: An Asian Perspective on Modernity and Politics in America. Singapoor: Marshall Cavendish.

Appadurai, A. 1996. Modernity at Large: Cultural Dimensions of Globalization. Minneapolis: University of Minnesota Press.

Attanayake, A. 2001. Globalization and Its Impact on Sri Lankan Culture, Popular Values and Predictions. Retrieved (https://dl.nsf.ac.lk/bitstream/1/5031/1/JSSpdf).

Barber, R. B. 2008. Consumed: How Markets Corrupt Children, Infantilize Adults, and Swallow Citizens Whole. New York: W.W. Norton \& Company.

Beck, U. 1992. The Risk Society: Toward a New Modernity. London: Sage Publications.

Bullis, D. 2005. The Mahavamsa: The Great Chronicle of Sri Lanka, Mahanama Thera: Modern Text and Historical Commentary. Sri Lanka: Vijitha Yapa Publication.

Castells, M. 1997. The Power of Identity: The Information Age: Economy, Society and Culture. Vol. II. Oxford: Blackwell Publishers.

. 2000. The Rise of the Network Society: The Information Age: Economy, Society and Culture. Vol. I. 2nd ed. Oxford: Wiley-Blackwell.

- 2010. The Rise of the Network Society: The Information Age: Economy, Society and Culture. Vol. I. 2nd ed. Oxford: Wiley-Blackwell.

Codrington, H. 2009. Sanksipta Lanka Itihasaya (Summary of Sri Lankan History). 4th ed. Colombo: Educational Publication Department.

De Silva, P. 2000. Globalization and the Transformation of Planetary Rituals in Southern Sri Lanka. Colombo: International Centre for Ethnic Studies.

Department of Census and Statistics. 2012. Census of Population and Housing 2012: Key Findings. Retrieved (http://countryoffice.unfpa.org/srilanka/drive/Census-2012. pdf).

Deraniyagala, S. U. 1988. The Prehistory of Sri Lanka: An Ecological Perspective. Michigan: Ann Arbor publication.

Geiger, W. 1912. The Mahavamsa or the Great Chronicle of Ceylone (English Translation). London: Oxford University Press.
Giddens, A. 2006. Sociology. 5th ed. USA: Polity Press.

- 2009. Sociology. 6th ed. USA: Polity Press.

Gill, S. 2000. "Toward a Postmodern Prince? The Battle in Seattle as a Moment in the New Politics of Globalisation." Millennium: Journal of International Studies 29(1):131-140.

Gombrich, R. F. 1988. Theravada Buddhism: A Social History From Ancient Benares to Modern Colombo. 2nd ed. London and New York: Routledge.

Halliday, F. 2000. "Getting Real About Seattle." Millennium: Journal of International Studies 29(1):123-129.

Hettige, S. T. 2000. "Globalisation and Local Culture: The Case of Sri Lanka." Pp. 169-204 in Sri Lanka at Crossroads: Dilemmas and Prospects After 50 Years of Independence, edited by S. T. Hettige and M. Mayer. New Delhi: Rajiv Beri for Macmillan India Limited.

Jayawardena, K. 2007. Nobodies to Somebodies: The Rise of the Colonial Bourgeoisie in Sri Lanka. Colombo: Social Scientists' Association.

Kaldor, M. 2000. "Civilising Globalisation?: The Implications of the Battle in Seattle." Millennium: Journal of International Studies 29(1):105-114.

Kapferer, B. 1983. A Celebration of Demons: Exorcism and the Aesthetic of Healing in Sri Lanka. Bloomington: Indian University Press.

Kinberg, M. 2009. "Review of the Book Cultural Globalization and Language Education." International Journal of Bilingual Education and Bilingualism 12(6):734-737.

Kumaravadivelu, B. 2008. Cultural Globalization and Language Education. New Haven, CT: Yale University Press.

Liu, Y. Q. 2012. "Exploring the Impacts of Cultural Globalization on Cultural Awareness/Values and English Writing in Chinese Context." Intercultural Communication Studies XXI(2):94-110.

Meyer, J. W. 1980. "The World Polity and the Authority of the Nation-State." Pp. 109-137 in Studies of the Modern World-System, edited by A. Bergesen. New York: New York Academic Press.

Meyer, J. W., J. Boli, G. M. Thomas, and F. O. Ramirez. 1997. "World Society and the Nation-State." American Journal of Sociology 103(1):144-181.

Moffitt, M. 1987. "Shocks, Deadlocks, and Scorched Earth: Reaganomics and the Decline of U.S. Hegemony." World Policy Journal 4(4):553-582.

Morrison, B. M. and S. H. Hasbullah, eds. 2004. Sri Lanka Society in an Era of Globalization: Struggling to Create a New Social Order. New Delhi: Sage Publications.

Peebles, P. 2006. The History of Sri Lanka. London: Greenwood Press.

Ranaweera Banda, R. M. 2013. Transnational Culture and 
Expert Knowledge: Responses From a Rural Community in Sri Lanka. Maharagama: Author Publication.

Rao, C. N. 2000. Sociology: Primary Principles of Sociology With an Introduction to Social Thought. New Delhi: S. Chand Publications.

Recherson, R. B. 2005. The Origin and Evolution of Cultures. UK: Oxford University Press.

Ritzer, G. 1996. The McDonaldization of Society: An Investigation Into the Changing Character of Contemporary Society. USA: Pince Forge Press.

- 2006. McDonaldization: The Reader. California: Pine Forge Press.

- 2010. Globalization: A Basic Text. United Kingdom: Wiley Blackwell.

Robertson, R. 1990. "Mapping the Global Condition: Globalisation as the Central Concept." Theory, Culture \& Society 7(2):15-30.

-1992. Globalisation: Social Theory and Global Culture. London: Sage.

-1997. "Glocalisation: Time-Space and Homogeneity-Heterogeneity." In Global Modernities, edited by M. Featherstone, S. Lash, and R. Robertson. Thousand Oaks, CA: Sage.

Scholte, J. 2000. Globalisation: A Critical Introduction. New York: St. Martin's Press.

Seligmann, C. G. and B. Z. Seligmann. 2003. The Veddas. New Delhi: Navrang Publishers.

Sharp, E. J. 1971. 50 Key Words Comparative Religion. London : Lutterworth Press.

Simon, D. 2007. "Globalisation, Geography and Environmental Security." In Globalisation: Theory and Practice, edited by E. Kofman and G. Youngs. New York: The Continuum International Publishing Group Inc.

Swartz, J. M. and K. J. David. 1980. Culture: The
Anthropological Perspective. New York: Johan Willey \& Sons.

Turner, B. S., ed. 2011. The Routledge International Handbook of Globalization Studies. New York: Routledge.

Wallerstein, I. 1974. The Modern World System: Capitalist Agriculture and the Origins of the European World Economy in the Sixteenth Century. New York: Academic Press.

. 1980. The Modern World-System II: Mercantilism and the Consolidation of the European World Economy. New York: Academic Press.

-1989. The Modern World-System III: The Second Era of Great Expansion of the Capitalist World Economy, 1730s-1840s. New York: Academic Press.

- 1998. Utopistics: Or, Historical Choices of the Twenty-First Century. New York: The New Press.

Yalman, N. 1967. Under the Bo Tree: Studies in Caste, Kinship, and Marriage in the Interior of Ceylon. Los Angeles: University of Calofornia Press.

Yogasundaram, N. 2006. A Comprehensive History of Sri Lanka From Prehistory to Tsunami. Colombo: Vijitha Yapa Publication.

Youngs, G. 2007. "International Relations as We Enter the Twenty-First Century." In Globalisation: Theory and Practice. 2nd ed., edited by E. Kofman and G. Youngs. New York, USA: Continuum.

\section{Bio}

Upali Pannilage, MPhil, senior lecturer, head of department, Department of Sociology, University of Ruhuna, Matara, Sri Lanka; research fields: sociology of development, globalisation, gender, conflict and peace studies. 